\title{
Populasi Kumbang Tanduk (Oryctes rhinoceros L.) Pada Kebun Kelapa Sawit Peremajaan Sistem Sisipan dan Tumbang Serempak Di Kecamatan Bahar Utara Kabupaten Muaro Jambi
}

\author{
${ }^{* 1}$ Hayata, ${ }^{1}$ Nasamsir dan ${ }^{2}$ Beni Afriansyah \\ ${ }^{1}$ Prodi Agroteknologi, Fakultas Pertanian Universitas Batanghari \\ ${ }^{2}$ Alumni Prodi Agroteknologi, Fakultas Pertanian Universitas Batanghari \\ J1. Slamet Riyadi, Broni Jambi, 36122. Telp. +62741 60103 \\ ${ }^{* 1}$ email korespondensi : hayatahayata82@gmail.com
}

\begin{abstract}
It is necessary to carry out replanting activities to increase the production and productivity of oil palm plants. Rejuvenation of oil palm plantations can be done through an underplanting system and totally rejuvenation system. The population propagation of horn beetles growed faster in oil palm plantations with inserting rejuvenation system than in totally rejuvenation system. This study aimed to obtain an accurate information on the population of horn beetles in oil palm plantations. The research has been conducted on July-August 2020 in Talang Bukit Village as an inserting system area Talang Datar Village as a totally rejuvenation area, Bahar Utara District, Muaro Jambi Regency, Jambi Province. An unformated trial was carried out as an experimental design and the location determination was purposively chosen for there were plants under study and showed a uniform condition at that location. the sampling locations based on oil palm plantation rejuvenation systems, namely: (1) inserting rejuvenation system, and (2) totally rejuvenation system. There were 15 / Ha population at oil palm plantation with inserting rejuvenation system, while there were 3 horn beetles/Ha in totally rejuvenation system. The percentage of horn beetle attacking was 22,22 in inserting rejuvenation system while it was only $3.70 \%$. in the totally rejuvenation system.
\end{abstract}

Keywords: population, horn beetle, rejuvenation, oil palm

\begin{abstract}
Abstrak. Dalam meningkatkan produksi dan produktivitas tanaman kelapa sawit perlu dilakukannya kegiatan peremajaan atau replanting. Peremajaan perkebunan kelapa sawit dapat dilakukan melalui system sisipan dan tumbang serempak. Populasi kumbang tanduk pada kebun kelapa sawit peremajaan sistem sisipan lebih cepat berkembang dibandingkan dengan sistem tumbang serempak. Penelitian ini bertujuan untuk mendapatkan informasi yang tepat populasi kumbang tanduk pada kebun kelapa sawit peremajaan sistem sisipan dan tumbang serempak. Penelitian pada bulan Juli sampai dengan Agustus 2020, dilaksanakan di Desa Talang Bukit untuk areal penanaman sisipan dan Desa Talang Datar untuk areal tumbang serempak Kecamatan Bahar Utara Kabupaten Muaro Jambi Provinsi Jambi. Percobaan di lakukan dengan Rancangan tidak terformat (Unformated Trials) dan lokasi dipilih secara sengaja (Purposive) karena pada lokasi tersebut terdapat tanaman yang diteliti dan seragam. Penentuan lokasi pengambilan sempel berdasarkan kepada kebun kelapa sawit peremajaan system yaitu Sisipan, dan tumbang serempak. Kebun kelapa sawit peremajaan sistem sisipan populasi kumbang tanduk terdapat sebanyak 15 ekor/Ha, sedangkan pada sistem tumbang serempak kumbang tanduk terdapat 3 ekor/Ha. Persentase tanaman kelapa sawit yang terserang hama kumbang tanduk peremajaan sistem sisipan didapatkan sebesar 22,22\%, sistem tumbang serempak hanya 3,70\%.
\end{abstract}

Kata kunci : populasi, kumbang tanduk, peremajaan sisipan, tumbang serempak

\section{PENDAHULUAN}

Kelapa sawit (Elaeis guineensis Jacq.) merupakan tanaman perkebunan yang mempunyai peran penting di Indonesia. Salah satu yang menjadi peranan penting kelapa sawit adalah mampu menciptakan lapangan kerja yang mengarah pada kesejahteraan masyarakat serta sebagai sumber perolehan devisa negara. Kelapa sawit merupakan tanaman palma yang menghasilkan minyak (CPO) yang dapat digunakan untuk tujuan komersil (Lubis, 2008).

Peningkatkan produksi dan produktivitas tanaman kelapa sawit perlu dilakukannya kegiatan revitalisasi dalam upaya percepatan pengembangan perkebunan rakyat. Salah satu aspek revitalisasi yang cukup penting yakni peremajaan atau replanting, alasan peremajaan dilakukan karena secara umum umur tanaman kelapa sawit di daerah tersebut berada diatas 20 tahun dan telah memasuki tahap akhir siklus produksi. Berdasarkan peraturan menteri pertanian republik Indonesia nomor 18/permentan/kb.330/5/2016 tentang pedoman peremajaan perkebunan kelapa sawit, terdapat empat macam sistem dalam peremajaan kelapa sawit, yaitu sistem tumbang serempak/total, sistem underplanting/sisipan, sistem peremajaan bertahap, dan sistem tumpang sari (intercropping) (Peraturan Menteri Pertanian RI, 2016).

Proses peremajaan yang dilakukan seperti metoda yang tersebut di atas ada keuntungan dan kelemahan, salah satu aspek yang sering dijumpai dalam peremajaan kelapa sawit adalah banyak ditemukannya hama Kumbang Tanduk (Oryctes rhinoceros) dan beberapa jenis hama lainnya. Kumbang tanduk merupakan hama yang utama menyerang tanaman kelapa sawit di Indonesia, khususnya di areal peremajaan kelapa sawit. O.rhinoceros menggerek pucuk kelapa sawit yang mengakibatkan terhambatnya pertumbuhan dan rusaknya titik tumbuh sehingga 
mematikan tanaman (Susanto dan Utomo, 2005). Hama O. rhinoceros menyerang tanaman kelapa sawit umur 2,5 tahun dengan merusak pelepah daun dan tajuk tanaman. Hal ini mengakibatkan produksi tandan buah segar mengalami penurunan mencapai 69\% pada tahun pertama. Selain itu, O. rhinoceros juga dapat mematikan tanaman muda mencapai $25 \%$. Ini disebabkan adanya tumpukan tandan kosong kelapa sawit atau sisa tumbuhan kayu yang sudah membusuk di lapangan sebagai tempat berkembang biak larva $O$ rhinoceros. Hama $O$. rhinoceros juga menyerang bagian pelepah daun yang belum membuka. Akibat serangan hama ini proses fotosintesis terganggu dan akan berpengaruh pada pertumbuhan serta produktifitas tanaman kelapa sawit (Darmadi, 2008 dalam Fajar, Tarmadja, Santi, 2017)

Perkebunan kelapa sawit rakyat di Kecamatan Bahar Utara Kabupaten Muaro Jambi secara umum telah berumur diatas 20 tahun, dan sebagian nya telah mulai melakukan peremajaan (replanting). Proses peremajaan tanaman sawit secara umum dilakukan dengan dua cara yaitu dengan cara menumbangkan batang yang sudah tua secara serempak lalu ditanam diantara titik tanam yang sudah ada. Yang kedua dengan cara melakukan penyisipan diantara batang sawit tua yang sudah ada. Pada kedua sistem tersebut ditemukan adanya Kumbang Tanduk. Seberapa besar populasi kumbang tanduk pada kebun kelapa peremajaan sistem sisipan dibandingkan dengan system tumbang serempak belum diketahui.

Pengamatan populasi dan intensitas serangan hama O.rhinoceros pada tanaman kelapa sawit secara rutin berperan penting didalam pengelolaan hama $O$. rhinoceros.

Penelitian ini bertujuan untuk mendapatkan informasi yang tepat populasi kumbang tanduk pada kebun kelapa sawit peremajaan sistem sisipan dan tumbang serempak.

\section{METODE PENELITIAN}

Penelitian dilakukan pada bulan Juli sampai dengan Agustus 2020. Lahan petani yang melakukan peremajaan kelapa sawit dengan cara sistem sisipan di Desa Talang Datar dan tumbang serempak di Desa Talang Bukit di Kecamatan Bahar Utara, Kabupaten Muaro Jambi

Bahan yang digunakan adalah tanaman kelapa sawit di lahan peremajaan sistem sisipan dan tumbang serempak berumur \pm 3 tahun, feromon, serangga yang tertangkap, air bersih, detergen, plastik transparan, kertas asturo warna kuning, formalin dan alkohol $70 \%$.

Alat yang digunakan dalam penelitian ini perangkap feromon (ferotrap), baskom, selotip, pinset, gunting, kalkulator, kamera, jarum suntik, buku kunci identifikasi dan alat tulis-menulis.

Percobaan di lakukan dengan rancangan tidak terformat (Unformated Trials) dan lokasi dipilih secara sengaja (Porposive) karena pada lokasi tersebut terdapat tanaman yang diteliti dan seragam. Penentuan lokasi pengambilan sempel berdasarkan kepada kebun kelapa sawit peremajaan sistem yaitu Sisipan dan tumbang total

Lahan kebun sawit yang dijadikan sebagai tempat penelitian ditentukan dengan secara sengaja dengan melihat keadaan kebun sesuai dengan yang diinginkan yaitu terdapat peremajaan tanaman kelapa sawit dengan sistem sisipan dan tumbang serempak berumur \pm 3 tahun

Untuk pengambilan sampel pada lokasi yang diamati seluas 1 hektar dipasang 5 perangkap. Penentuan titik sampel dilakukan secara sistematis diagonal pada masing-masing lokasi.

\section{Peubah yang Diamati meliputi :}

\section{Populasi Kumbang Tanduk (ekor/Ha)}

Pengamatan populasi kumbang tanduk dilakukan dengan menggunakan perangkap (Ferotrap). Perangkap yang digunakan berjumlah 5 buah dan diletakkan pada tiap titik lokasi sampel. Pengamatan dilakukan sekali seminggu selama 6 minggu, dengan menghitung jumlah kumbang tanduk yang masuk dalam perangkap, dan langsung dimasukkan ke dalam toples dan diberi label.

\section{Persentase Serangan}

Persentase serangan dihitung adalah jumlah batang yang terserang oleh kumbang tanduk dalam satu hektar, dihitung dengan rumus;

$\%$ Serangan $=$ Jumlah batang yang tserangan kumbang tanduk $\quad \times 100 \%$

\section{Tindakan Agronomi}

$$
\text { Jumlah batang dalam } 1 \mathrm{Ha}
$$

Pengamatan tindakan Agronomi diambil dengan cara, petani diminta mengisi lembaran kuisoner, yaitu dengan wawancara yang bersifat terpimpin kepada petani meliputi bahan tanam, pengendalian hama/penyakit, pengendalian gulma dan pemupukan.

Data yang diperoleh dalam penelitian ini ditabulasi dan dianalisis secara deksriptif, dan disajikan dalam bentuk tabel dan grafik. 
Hayata, Nasamsir, dan Beni Afriansyah. Populasi Kumbang Tanduk (Oryctes rhinoceros L.) Pada Kebun Kelapa Sawit Peremajaan Sistem Sisipan Dan Tumbang Serempak Di Kecamatan Bahar Utara Kabupaten Muaro Jambi

\section{Populasi Hama Kumbang Tanduk}

\section{HASIL DAN PEMBAHASAN}

Pengamatan populasi kumbang tanduk pada kebun sawit peremajaan sistem sisipan dan tumbang serempak yang diamati selama 6 minggu menggunakan perangkap feromon didapatkan hasilnya yang disajikan pada Tabel 1 berikut.

Tabel 1. Populasi hama kumbang tanduk pada kebun sawit peremajaan sistem sisipan dan tumbang serempak yang diamati selama 6 minggu

\begin{tabular}{ccc}
\hline \multirow{2}{*}{ Mingu ke- } & \multicolumn{2}{c}{ Jumlah yang masuk perangkap (ekor/Ha) } \\
& \multicolumn{2}{c}{ Sistem peremajaan } \\
\cline { 2 - 3 } & Sisipan & Tumbang serempak \\
\hline 1 & - & - \\
2 & 3 & - \\
3 & 7 & 2 \\
4 & 5 & - \\
5 & - & - \\
6 & - & 3 \\
\hline
\end{tabular}

Berdasarkan Tabel 1 di atas diketahui pengamatan pertama pada masing-masing lahan tidak ditemukan kumbang tanduk pada perangkap. Pada pengamatan minggu ke tiga pada lahan sisipan ditemukan 7 ekor kumbang tanduk dan pada lahan tumbang serempak ditemukan 2 ekor kumbang tanduk. Pada pengamatan minggu keempat pada lahan sisipan ditemukan 5 ekor, dan pada lahan Tumbang serempak hanya ditemukan 1 ekor. Pengamatan minggu ke lima dan keenam tidak didapatkan kumbang tanduk pada perangkap. Jumlah keseluruhan yang masuk perangkap feromon adalah 18 ekor kumbang tanduk, yang terdiri dari pada lahan peremajaan kelapa sawit di sistem sisipan sebanyak 15 ekor/Ha, dan pada sistem tumbang serempak hanya 3 ekor/Ha.

Populasi kumbang tanduk pada lahan peremajaan sistem sisipan ditemukan sebanyak 15 ekor/Ha, sepertinya keadaan ini tidak dilakukan pengendalian oleh petani, hal ini terlihat dari tindakan agronomi yang dilakukan petani bahwa selama melakukan proses peremajaan tidak ada dilakukan pengendalian (Tabel 3).

Banyaknya populasi yang didapatkan pada lahan kebun sawit peremajaan sistem sisipan, hal tersebut dipengaruhi oleh kondisi areal kelapa sawit sistem sisipan banyak ditemukan tunggul-tunggul kelapa sawit yang dibiarkan membusuk secara perlahan merupakan salah satu jenis sarang untuk peletakan telur bagi imago kumbang kelapa. Batang pohon yang telah mati dan tidak ditebang juga sarang larva kumbang tanduk untuk berkembang. Menurut Moore (2015) dalam Nuriyanti, Widhiono, dan Suyanto, (2016) bahwa pohon kelapa yang dibiarkan tetap berdiri setelah mati dan tandan bunga kelapa dapat menjadi tempat kumbang badak berkembang biak. Menurut Yustina, Fauziah dan Sofia. (2012) sampah yang membusuk dan tandan kosong sawit yang tersisa setelah pemanenan dan daun-daun yang telah membusuk, kondisi seperti ini merupakan tempat yang sangat cocok untuk kumbang badak berkembang. Sedangkan pada areal peremajaan sistem tumbang serempak menekan resiko sekecil mungkin adanya serangan hama kumbang tanduk.

\section{Persentase Tanaman Kelapa Sawit yang Terserang Hama Kumbang Tanduk}

Persentase tanaman kelapa sawit yang terserang oleh hama kumbang tanduk pada kebun sawit peremajaan sistem sisipan dan tumbang serempak dapat dilihat pada Tabel 2, dibawah.

Tabel 2. Persentase tanaman kelapa sawit yang terserang hama kumbang tanduk pada kebun sawit peremajaan sistem sisipan dan tumbang serempak

\begin{tabular}{ccc}
\hline Sistem peremajaan & Jumlah Pohon terserang/ha & Persentase \% \\
\hline Sisipan & 30 & 22,22 \\
Tumbang Serempak & 5 & 3,70 \\
\hline
\end{tabular}

Berdasarkan Tabel 2 di atas, dapat dilihat bahwa persentase serangan hama kumbang tanduk pada lahan kelapa sawit system sisipan lebih tinggi dibandingkan sistem tumbang serempak. Persentase serangan hama kumbang tanduk dilahan kelapa sawit system sisipan sebesar 22,22\% (30 batang yang terserang dari 135 batang/ha) dan pada system tumbang serempak sebesar 3,70\% (5 batang yang terserang dari 135 batang/ha).

Banyaknya jumlah tanaman sawit yang terserang oleh hama kumbang tanduk pada lahan sawit peremajaan sistem sisipan, hal itu disebabkan karena populasi hama kumbang tanduk yang terdapat pada lahan tersebut juga 
lebih tinggi dibandingkan dengan lahan peremajaan kebun sawit sistem tumbang serempak. Tersedianya bahan makanan dan tempat bersarang bagi kumbang tanduk pada lahan sawit peremajaan sistem sisipan akan menyebabkan tanaman sawit juga terserang lebih banyak. Menurut Andrewartha dan Birch (1954) dalam Nuriyanti, Widhiono, Suyanto, (2016) bahwa faktor-faktor yang mempengaruhi pertumbuhan, perkembangan, dan kerapatan populasi adalah tersedianya sumberdaya seperti makanan dan ruang tempat hidup serta aksesibilitas sumberdaya dan kemampuan individu-individu populasi untuk mencapai dan memperoleh sumberdaya (antara lain sifat penyebaran, pemencaran dan kemampuan mencari)

\section{Tindakan Agronomi}

Tindakan agronomi yang dilakukan oleh petani dalam mengelola tanaman sawit pada peremajaan sistem sisipan dan tumbang serempak dapat dilihat pada Tabel 3 dibawah.

Tabel 3. Tindakan agronomi yang dilaksanakan oleh petani pada kebun sawit peremajaan sistem sisipan dan tumbang serempak

\begin{tabular}{|c|c|c|c|}
\hline \multirow{2}{*}{\multicolumn{2}{|c|}{ Tindakan Agronomi }} & \multicolumn{2}{|c|}{ Sistem Peremajaan } \\
\hline & & Sisipan & Tumbang serempak \\
\hline \multicolumn{4}{|c|}{ Bibit: } \\
\hline a. & Varietas & Tenera & Tenera \\
\hline b. & Cara Peroleh & PTPN VI, bibit pangkas & PTPN VI \\
\hline \multicolumn{4}{|c|}{ Pupuk: } \\
\hline a. & Jenis Pupuk & Urea, SP36, KCL & Urea dan NPK \\
\hline b. & Waktu Pemupukan & fluktuatif & fluktuatif \\
\hline c. & Intensitas Pemupukan & $3 \mathrm{kali} / \mathrm{th}$ & $2-3 \mathrm{kali} / \mathrm{th}$ \\
\hline \multicolumn{4}{|c|}{ Herbisida: } \\
\hline & & Tidak Pernah & Tidak Pernah \\
\hline & & Tidak Pernah & Tidak Pernah \\
\hline \multicolumn{4}{|c|}{ Intensitas Pengendalian: } \\
\hline a. & Gulma & Jika Rumput Tinggi & Jika Rumput Tinggi \\
\hline b. & Penyakit & Tidak Pernah & Tidak Pernah \\
\hline c. & Hama & Tidak Pernah & Tidak Pernah \\
\hline
\end{tabular}

Petani yang melaksanakan peremajaan sistem sispan dan tumbang serempak menggunakan bibit dengan varietas tenera, namun cara mendapatkannya berbeda. Petani peremajaan sisipan mendapatkan bibit tanam dari PTPN 6 melalui penangkar yang telah melalui proses pemangkasan daun hal tersebut menunjukkan bahwa bibit tanam sudah lewat masa tanamnya, sedangkan Petani peremajaan tumbang serempak mendapatkan bibit tanam langsung dari PT. Perkebunan Nusantara VI (PTPN 6).

Pemupukan yang dilakukan oleh petani pada peremajaan sistem sisipan lebih lengkap dibandingkan dengan sistem tumbang serempak, hal ini terlihat dari jenis pupuk yang digunakan yaitu pupuk Urea, SP36, dan KCL dengan intensitas pemupukan 3 kali dalam satu tahun. Sedangkan pada peremajaan sistem tumbang serempak petani menggunakan pupuk Urea dan NPK dengan intensitas pemupukan 2 atau 3 kali dalam satu tahun.

Pengendalian Gulma pada peremajaan sistem sisipan dan tumbang serempak dilakukan bila gulma telah banyak tumbuh dan tinggi.

Pengendalian penyakit tidak dilakukan baik pada peremajaan sistem sisipan maupun tumbang serempak, hal ini disebabkan tidak adanya penyakit yang tampak dan merugikan terhadap tumbuhan tanaman sawit.

Pengendalian hama juga tidak dilakukan, walaupun terpantau ada keberadaan hama kumbang tanduk, tapi petani tidak menanggulanginya, karena keberadaan kumbang tanduk menurut petani belum mempengaruhi terhadap pertumbuhan tanaman sawit.

\section{KESIMPULAN}

Populasi kumbang tanduk pada kebun kelapa sawit peremajaan sistem sisipan sebanyak 15 ekor/Ha, sedangkan pada sistem tumbang serempak kumbang tanduk terdapat 3 ekor/Ha. Persentase tanaman kelapa sawit yang terserang hama kumbang tanduk peremajaan sistem sisipan didapatkan sebesar $22,22 \%$, sedangkan sistem tumbang serempak hanya $3,70 \%$. 
Hayata, Nasamsir, dan Beni Afriansyah. Populasi Kumbang Tanduk (Oryctes rhinoceros L.) Pada Kebun Kelapa Sawit Peremajaan Sistem Sisipan Dan Tumbang Serempak Di Kecamatan Bahar Utara Kabupaten Muaro Jambi

\section{DAFTAR PUSTAKA}

Fajar J., Tarmadja S., Santi I S., 2017. Pengaruh Ferotrop Terhadap Tangkapan Hama Kumbang Tanduk (Oryctes rhinoceros) Pada Kelapa Sawit di sekitar Ferotrop. Jurnal Agromast, Vol 2 no 1, April 2017.

Lubis, A.U. 2008. Kelapa Sawit (Elaeis guineensis Jacq) di Indonesia Edisi ke-2 Pusat Penelitian Kelapa Sawit. Medan, 232 hal.

Peraturan Menteri Pertanian RI]. 2016. Pedoman Peremajaan Perkebunan Kelapa Sawit. Direktur Jenderal Peraturan Perundang-Undangan Kementerian Hukum Dan Hak Asasi Manusia Republik Indonesia

Susanto, A. dan Utomo. 2005. Ulat Pemakan Daun kelapa Sawit, Jenis Kerusakan dan Pengendaliannya. Pusat Penelitian Kelapa Sawit Medan.

Nuriyanti, D D, Widhiono I., dan Suyanto A., 2016. Faktor-faktor Ekologis yang Berpengaruh Terhadap Struktur Populasi Kumbang Badak (Oryctes rhinoceros L. ) Jurnal Biosfera, Vol. 33 No.1, Januari 2016, 13-21

Yustina, Y, Fauziah, dan R Sofia.2012.Struktur Populasi Kumbang Tanduk (Orycetes rhinoceros) Di Area Perkebunan Kelapa Sawit Masyarakat Desa Kenantan Kabupaten Kampar Riau. Jurnal Biogenesis, $8(2): 54-63$ 